\title{
PERANCANGAN SISTEM INFORMASI PEMBAYARAN CUSTOMER PADA SALON KECANTIKAN QEEMONTSALY BERBASIS JAVA NETBEANS
}

\author{
Gintan Dwi Anggraini ${ }^{1}$, Lusi Ariyani ${ }^{2}$, Dyah Rhetno Wardhani ${ }^{3}$ \\ Program Studi Teknik Informatika, Fakultas Teknik dan Ilmu Komputer, \\ Universitas Indraprasta PGRI \\ Jalan Raya Tengah No 80, Kelurahan Gedong, Pasar Rebo, Jakarta Timur \\ gintananggraini37@gmail.com¹, lusiariyani0312@gmail.com², dyahrhetno@gmail.com³
}

\begin{abstract}
Abstrak
Salon kecantikan Qeemontisaly merupakan suatu badan usaha yang bergerak dalam bidang jasa memotong rambut dan menjual produk vitamin rambut. Permasalahan dari sistem pembayaran customer pada salon kecantikan Qeemontialy yaitu sistem pembayaran dalam melakukan pengelolaan data masih kurang optimal dan terdapat kesalahan dalam memasukan data, lamanya proses perhitungan, dan sulitnya membuat laporan yang diakibatkan karena sistem yang diterapkan masih bersifat manual dengan mencatat di buku. Dari persoalan tersebut, peneliti tertarik untuk merancang sistem pembayaran customer pada salon kecantikan Qeemontisaly yang ada saat ini sehingga dapat mengatasi kekurangan yang ada. Dengan menggunakan metode pengembangan sistem yaitu Grounded Research dalam penelitian ini adalah dengan tahapan-tahapan seperti analisa untuk perancangan sistem, studi kepustakaan dan studi literatur, pengumpulan data dan perancangan konsep sistem, desain, pengujian sistem, presentasi sistem dan implementasi dan terakhir pembuatan laporan. Hasil dari penelitian ini adalah memudahkan karyawan dalam melakukan pengelolaan data yang sudah terkomputerisasi sehingga dapat berlangsung secara efektif dan efisien.
\end{abstract}

Kata Kunci : Perancangan Sistem Informasi, Pembayaran, Pembayaran Customer, Berbasis Java, Netbeans.

\begin{abstract}
Qemontisaly beauty salon is a business entity that is engaged in hair cutting services and selling hair vitamin products. The problem with the customer payment system at the Qeemontialy beauty salon is that the payment system in managing data is still not optimal and there are errors in entering data, the length of the calculation process, and the difficulty of making reports caused because the system applied is still manual by recording in the book. From these problems, researchers are interested in designing a customer payment system at the current Qemontisaly beauty salon so that it can overcome the existing shortcomings. By using the system development method, namely Grounded Research, in this research, there are stages such as analysis for system design, literature study and literature study, data collection and system concept design, design, system testing, system presentation and implementation and finally report generation. The result of this research is to make it easier for employees to manage computerized data so that it can take place effectively and efficiently.
\end{abstract}

Keyword : Information System Design, Payment, Customer Payment, Java Based, Netbeans.

\section{PENDAHULUAN}

Dalam hal mengelola data dan transaksi di suatu bidang pelayanan jasa, penggunaan komputer sangat di butuhkan karena komputer di gunakan sebagai alat bantu untuk melakukan aktivitas. Misalnya pengelolaan data, penyimpanan data, dan pembuatan laporan. Dengan memanfaatkan teknologi komputer, memudahkan pelayanan menggunakan sistem komputerisasi. (Riyanto, 2010) perancangan merupakan tahap yang harus dilakukan sebelum dilakukan pembuatan dan implementasi aplikasi. Perancangan Sistem adalah sekumpulan aktivitas yang menggambarkan secara rinci bagaimana sistem akan berjalan. Hal ini bertujuan untuk menghasilkan produk perangkat lunak yang sesuai dengan kebutuhan user (Satzinger et al., 2012). Sistem adalah entitas atau satuan yang terdiri dari dua atau lebih komponen atas subsistem yang saling terhubung dan saling berkaitan untuk mencapai tujuan yang sama (Tantra, 2012). Informasi sebagai data yang sudah diubah menjadi konteks yang bermakna dan berguna bagi pengguna akhir yang spesifik 
(O’Brien \& Marakas, 2014). Sistem informasi mencakup sejumlah komponen (manusia, komputer, teknologi informasi, dan prosedur kerja), ada sesuatu yang diproses (data menjadi informasi), dan dimaksudkan untuk mencapai suatu sasaran atau tujuan (Kadir, 2014). Pembayaran adalah berpindahnya hak pemilikan atas sejumlah uang atau dan dari pembayar kepada penerimanya, baik langsung maupun melalui media jasa-jasa perbankan (Malayu, 2010). Pelanggan atau customer adalah individu atau kelompok yang terbiasa membeli sebuah produk atau jasa berdasarkan keputusan mereka atas pertimbangan manfaat maupun harga yang kemudian melakukan hubungan dengan perusahaan melalui telepon, surat, dan fasilitas lainnya untuk mendapatkan suatu penawaran baru dari perusahaan (Greenberg, 2010). Perangkat komputer sangat dibutuhkan guna memudahkan membuat laporan dan data customer sangat berguna untuk membantu kerja karyawan setiap harinya. Dengan adanya sistem pembayaran customer yang telah terkomputerisasi banyak sekali keuntungan yang diperoleh oleh pihak salon Qeemontisaly seperti memudahkan karyawan dalam melakukan pengelolaan data yang sudah terkomputerisasi sehingga dapat berlangsung secara efektif dan efisien, serta memudahkan karyawan dalam melakukan pencetakan laporan setiap bulannya.

\section{PENELITIAN RELEVAN}

Dalam penelitian yang berjudul Rancang Bangun Sistem Informasi Jasa Barbershop Dan Coffee Pada Gentlemen Barbershop And Coffee (Welim \& Afifi, 2017). Penelitian ini bertujuan untuk membuat dan mengimplementasikan sistem aplikasi yang efektif dan efesien. Hasil penelitian meningkatkan kualitas dalam kegiatan pelayanan, menciptakan sebuah sistem yang fleksibel, efisien, dan efektif, mempermudah dalam penyajian data yang cepat, akurat, serta up-to-date, dan mengurangi kesalahan dalam proses transaksi dan pembuatan laporan. Penelitisn oleh (Supriyanto, 2016) dengan judul Sistem Informasi dan Administrasi pada Boutique Tradisional. Penelitian ini bertujuan untuk membuat sistem aplikasi merancang sebuah program aplikasi dalam proses pengelolaan data dan informasi dan administrasi. Hasil penelitian ini terciptanya aplikasi desktop berbasis java yang sangat membantu bagian administrasi.

\section{METODE PENELITIAN}

Metode penelitian yang digunakan oleh peneliti adalah metode grounded. (Greenberg, 2010) menjelaskan grounded theory or grounded methodology is most often derived from data sources of aqualitative. Penelitian dilakukan di Salon Kecantikan Qeemontisaly Jalan Kebantenan IV RT.01, RW.03, Semper Tim,. Cilincing, Jakarta Utara.

\section{Metode Pengumpulan Data}

1. Studi Kepustakaan, data yang didapatkan berupa data sekunder. Peneliti mempelajari bukubuku kepustakaan Universitas Indraprasta PGRI, mencari informasi melalui jurnal-jurnal ilmiah dan ebook online mengenai sistem informasi pembayaran customer.

2. Metode Lapangan, secara langsung untuk mengumpulkan data yang berhubungan dengan sistem komputerisasi yang terdapat di Salon Kecantikan Qeemontisaly. Data tersebut peneliti kumpulkan dengan cara:

a. Observasi. Peneliti mengamati secara langsung proses sistem pembayaran antara customer dan karyawan Salon Kecantikan Qeemontisaly masih secara manual dengan mencatat di buku.

b. Wawancara. Peneliti menyiapkan pertanyaan kepada karyawan mengenai bagaimana sistem pembayaran customer yang berjalan pada Salon Kecantikan Qeemontisaly.

c. Dokumentasi. Peneliti melakukan pengumpulan data dengan mencatat data yang ada pada dokumen atau arsip Salon Kecantikan Qeemontialy. 


\section{HASIL DAN PEMBAHASAN}

\section{Analisa Permasalahaan}

Setelah menganalisa sistem yang berjalan, peneliti menyimpulkan bahwa untuk mempermudah seluruh aktivitas pekerjaan mengelola, menyimpan dan mencetak laporan, maka peneliti merancang sistem informasi pembayaran customer pada salon kecantikan Qeemontisaly.

\section{Normalisasi}

Normalisasi adalah proses pengelompokan data kedalam bentuk tabel atau relasi atau file untuk menyatakan entitas dan hubungan sehingga terwujud satu bentuk database yang mudah untuk dimodifikasi, ada beberapa bentuk normalisasi(Ladjamudin, 2013:120).

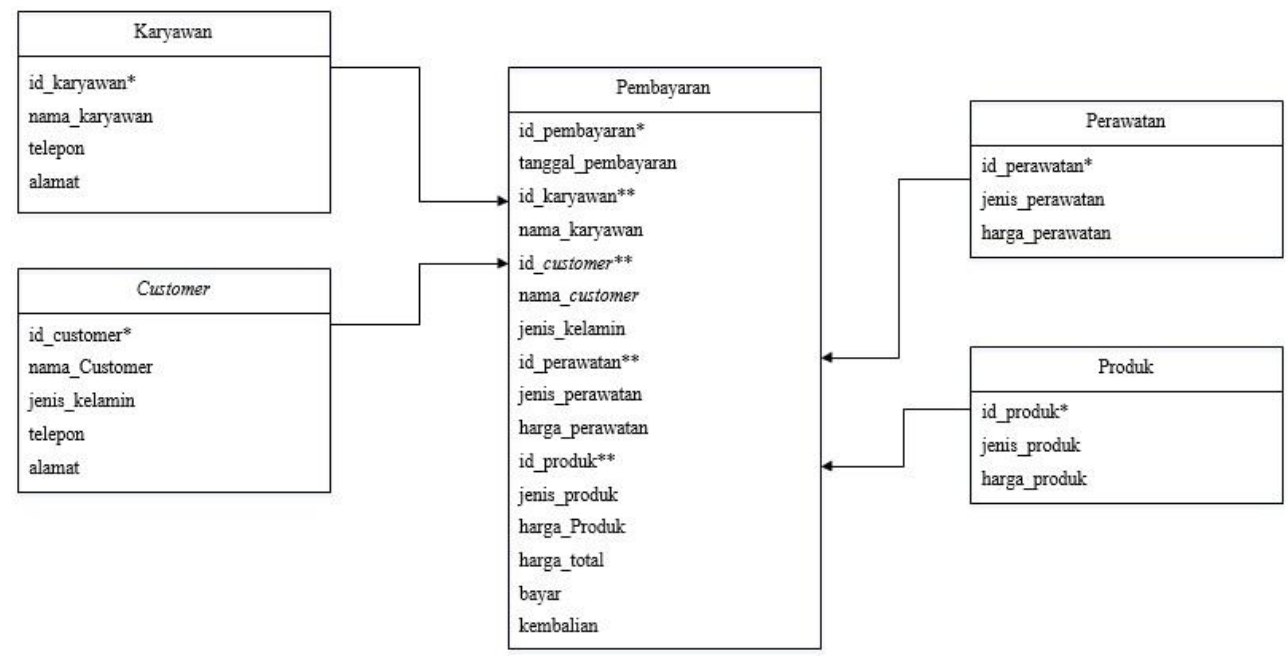

Gambar 2. Normalisasi

\section{Tampilan Aplikasi}

Berikut ini hasil perancangan sistem informasi pembayaran customer pada salon kecantikan Qeemontisaly.

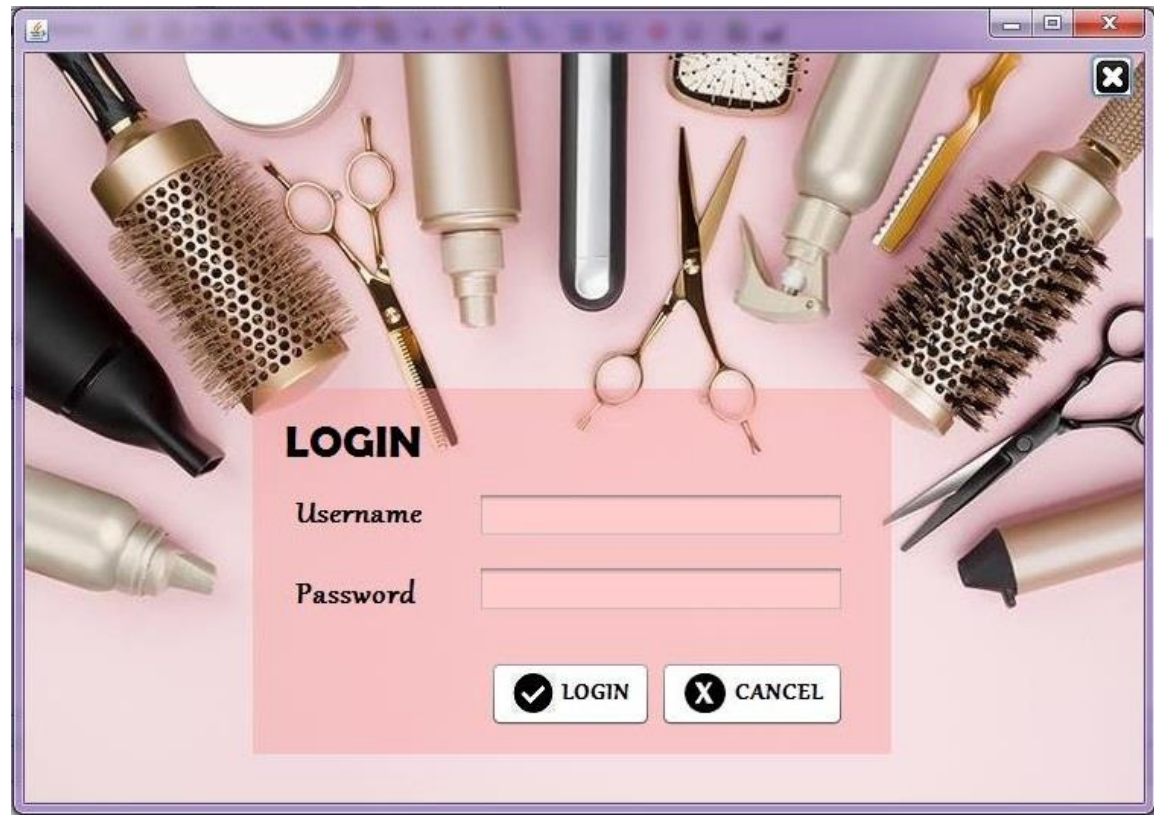

Gambar 3. Tampilan Menu Login

Pada gambar 3 diatas menampilkan form untuk login. 


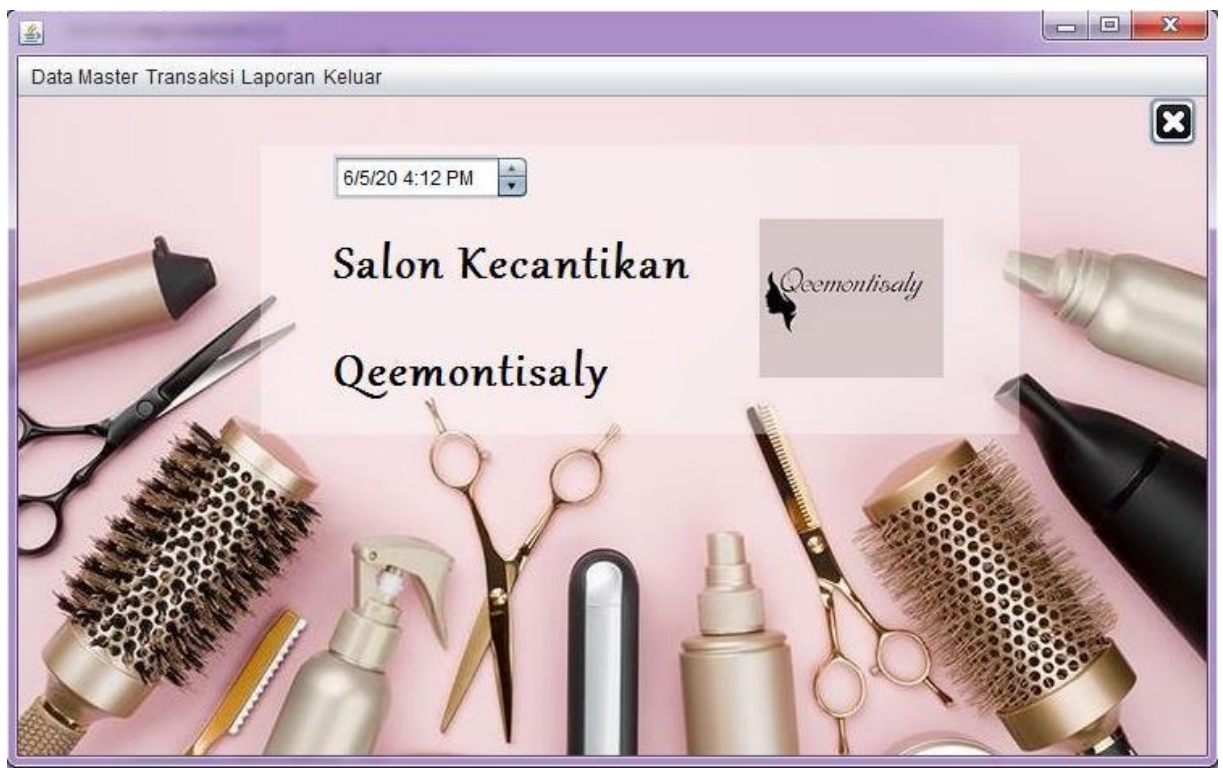

Gambar 4. Tampilan Menu Utama

Pada layar ini terdapat sebuah menu bar yang berisikan Data Master, Transaksi, Laporan dan Keluar.

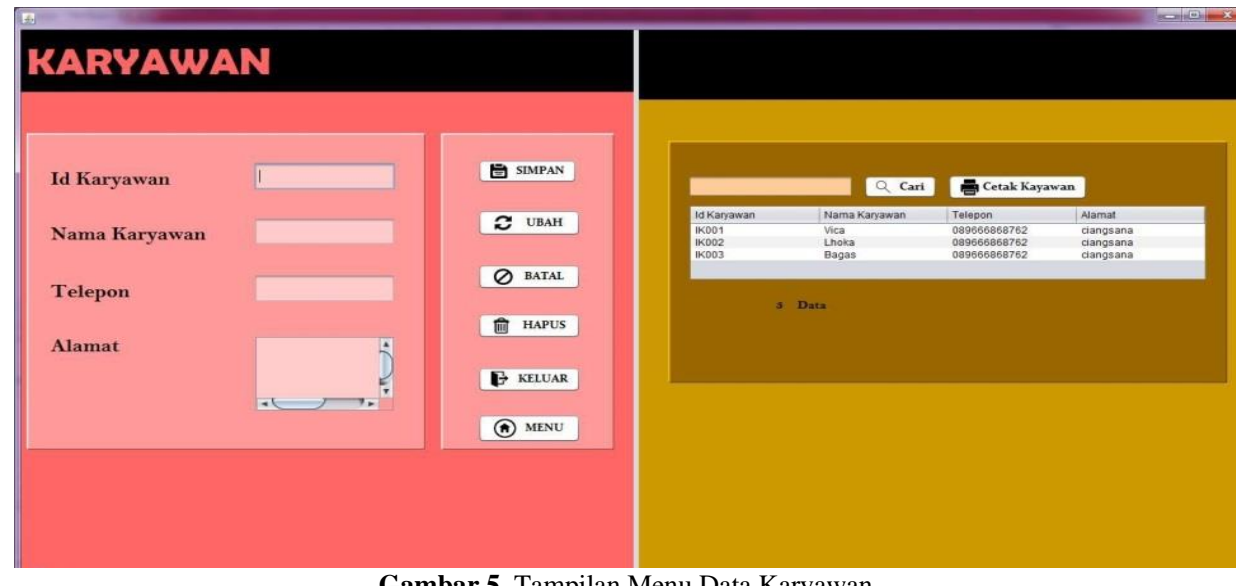

Gambar 5. Tampilan Menu Data Karyawan

Pada tampilan diatas merupakan tampilan menu data karyawan.

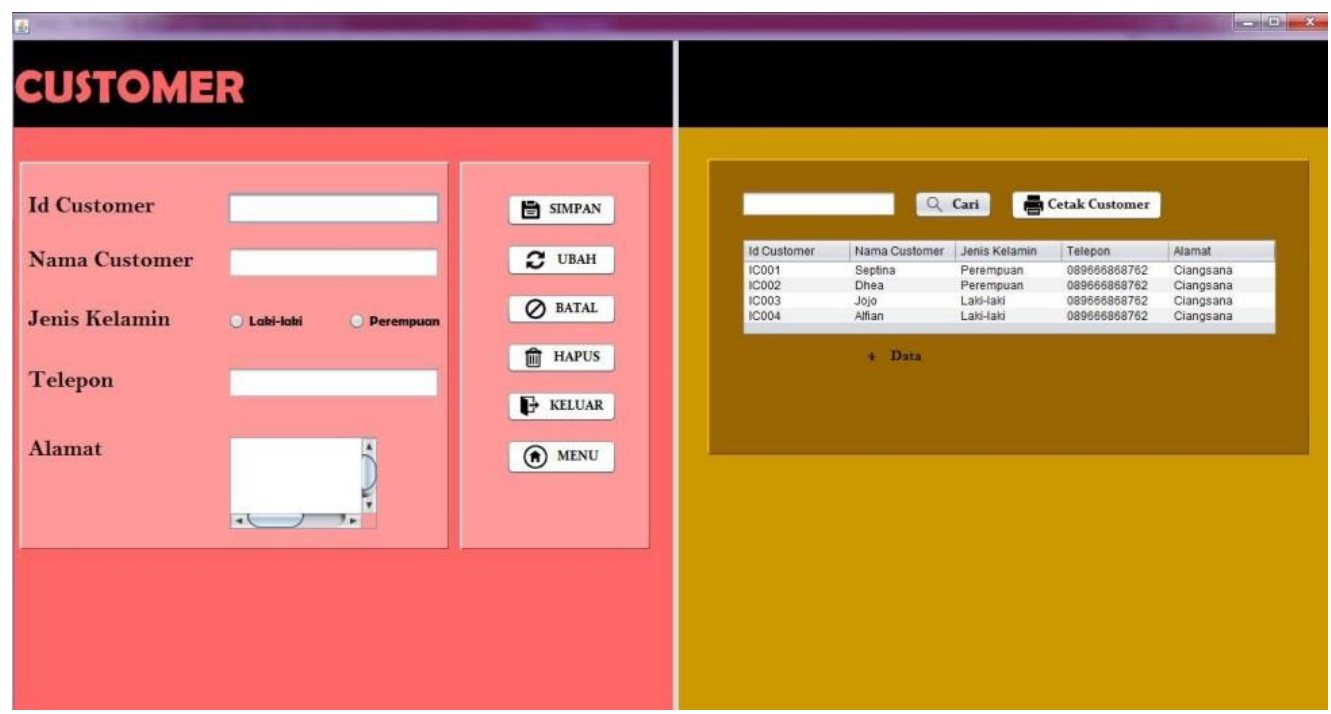

Gambar 6. Tampilan Menu Data Customer 
Jurnal Riset dan Aplikasi Mahasiswa Informatika (JRAMI)

Vol Q2 No Q3 Tahun ZOZI

e-ISSN : $2715-8756$

Pada tampilan diatas merupakan tampilan menu data customer.

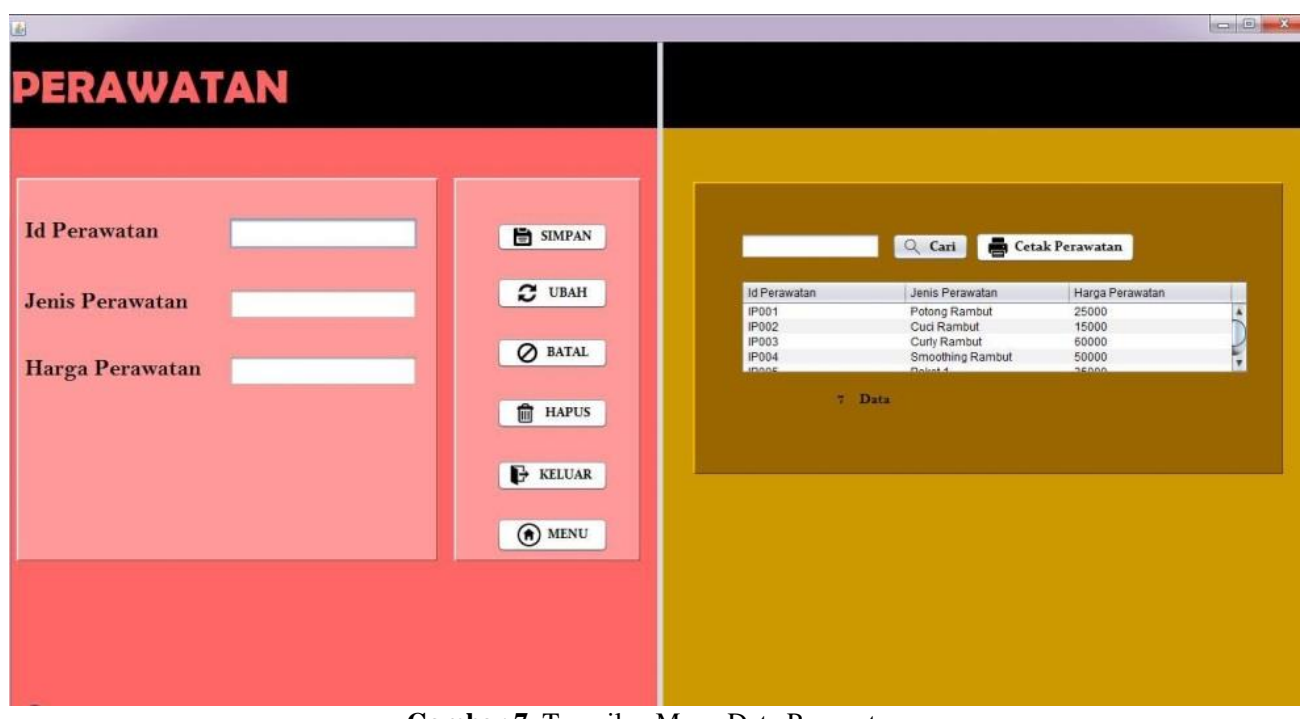

Gambar 7. Tampilan Menu Data Perawatan

Pada tampilan diatas merupakan tampilan menu data perawatan.

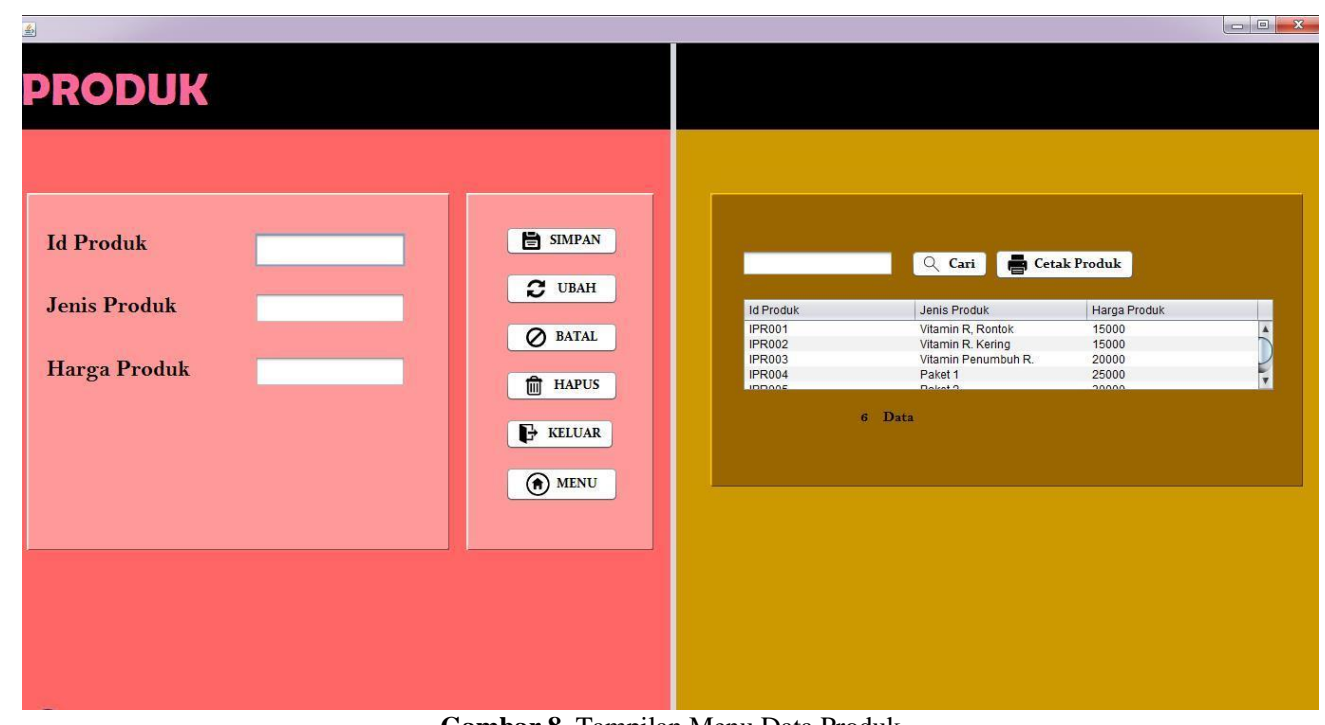

Gambar 8. Tampilan Menu Data Produk

Pada tampilan diatas merupakan tampilan menu data produk. 
Jurnal Riset dan Aplikasi Mahasiswa Informatika (JRAMI)

Vol Q2 No Q3 Tahun ZOZI

e-ISSN : $2715-8756$

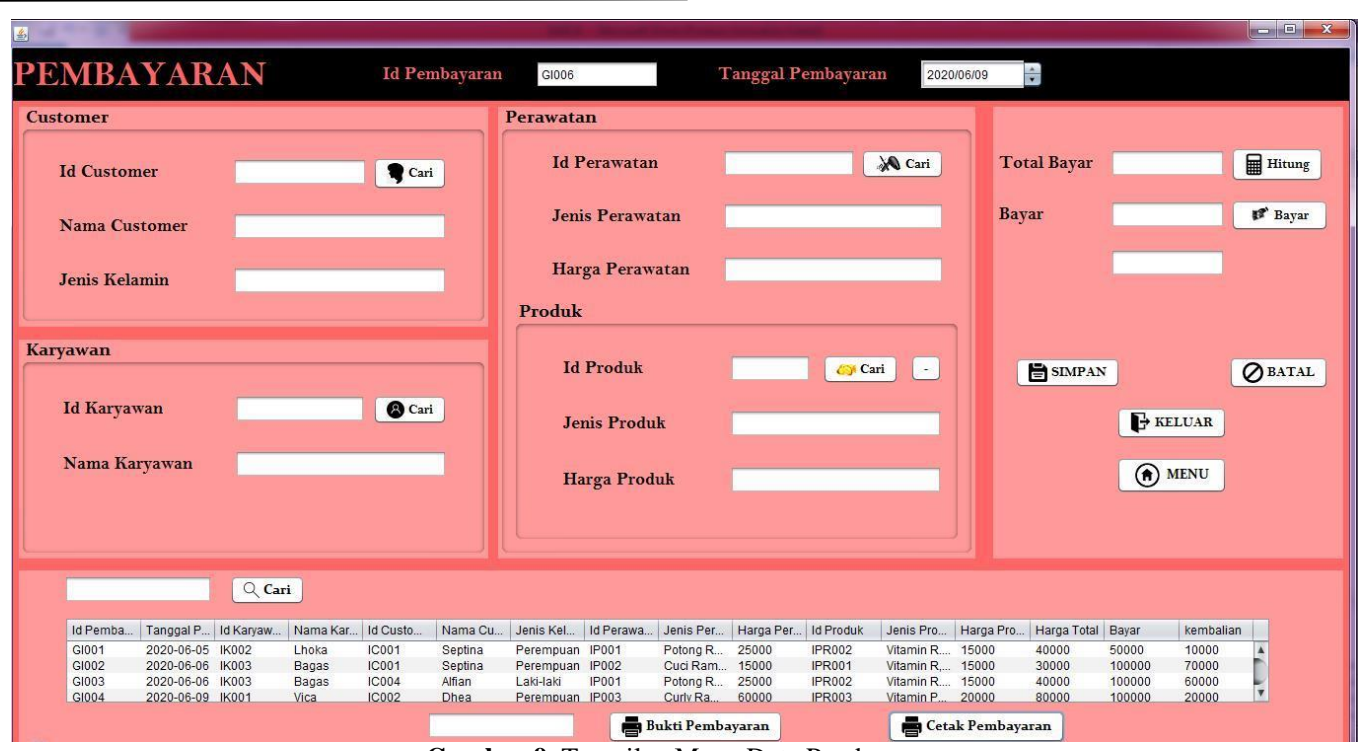

Gambar 9. Tampilan Menu Data Pembayaran

Pada tampilan diatas merupakan tampilan menu data pembayaran.

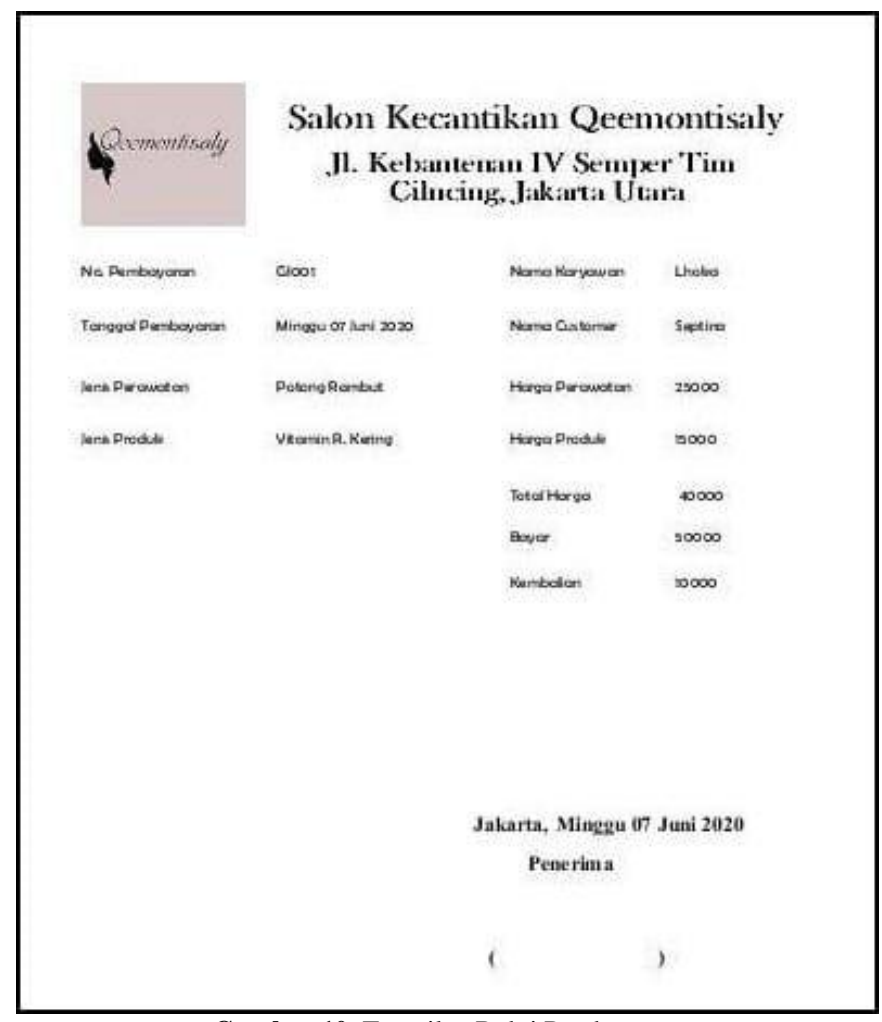

Gambar 10. Tampilan Bukti Pembayaran

Pada tampilan diatas merupakan tampilan bukti pembayaran. 


\section{Laporan Data Pembayaran}

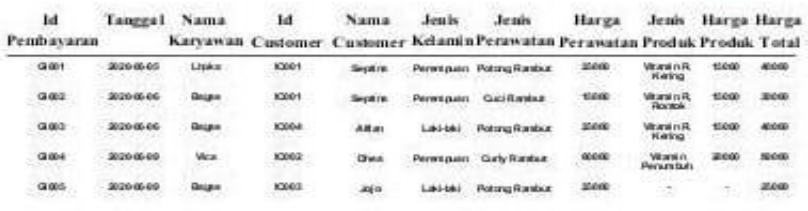

Jakarta, Selasa 09 Juni 2020 Pemilik

Niamat

Gambar 11. Tampilan Laporan Pembayaran

Pada tampilan diatas merupakan tampilan laporan pembayaran.

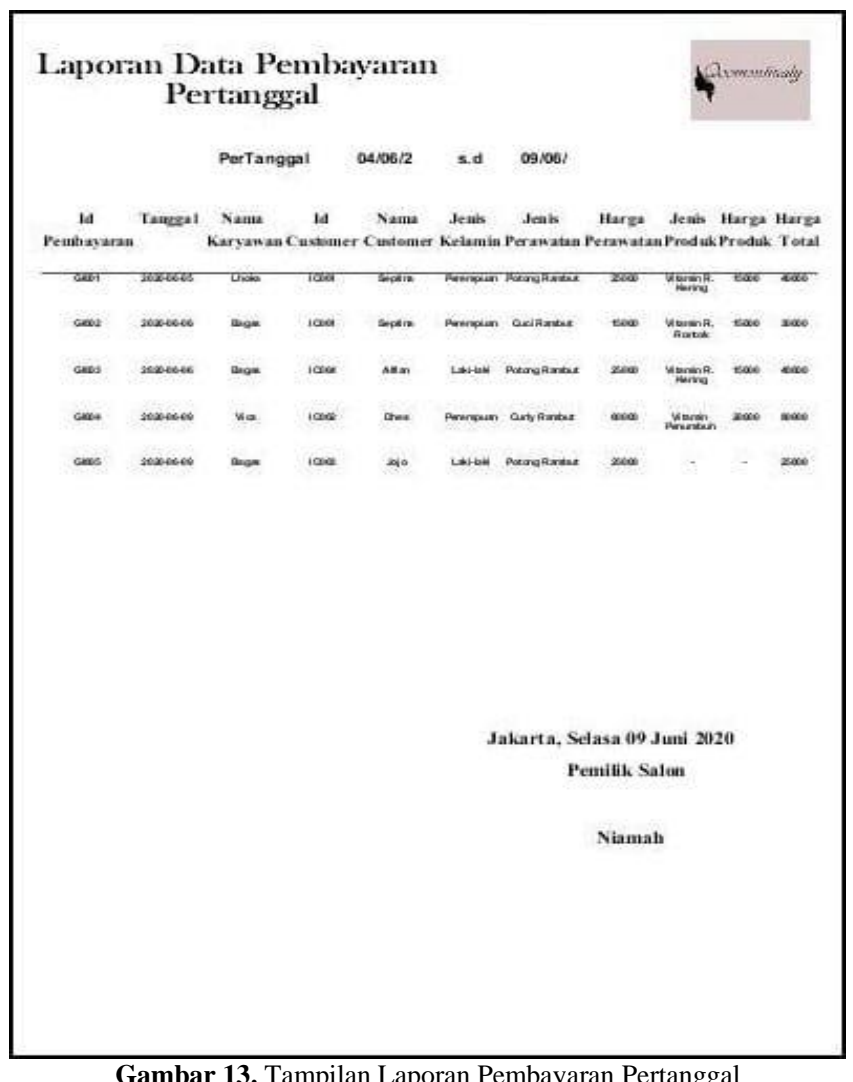

Gambar 13. Tampilan Laporan Pembayaran Pertanggal

Pada tampilan diatas merupakan tampilan bukti pembayaran pertanggal 


\section{SIMPULAN}

Dengan adanya aplikasi pembayaran customer berbasis komputer di Salon Kecantikan Qeemontisaly membuat sistem menjadi fleksibel, efektif dan efisien, meningkatkan kualitas dalam kegiatan pelayanan, mempermudah dalam penyajian data yang cepat, akurat, serta up-to-date, dan mengurangi kesalahan dalam proses transaksi dan pembuatan laporan

\section{DAFTAR PUSTAKA}

Greenberg, P. (2010). CRM at the Speed of Light, Fourth Edition: Social CRM 2.0 Strategies, Tools, and Techniques for Engaging Your Customers. McGraw-Hill Education.

Kadir, A. (2014). Pengenalan Sistem Informasi Edisi Revisi. Andi Offset.

Ladjamudin, A.-B. Bin. (2013). Analisis dan desain sistem informasi. Graha ilmu.

Malayu, H. (2010). Manajemen sumber daya manusia. PT Bumi Aksara.

O’Brien, J. A., \& Marakas, G. M. (2014). Sistem Informasi Manajemen Buku 1 -9/E. Salemba Empat.

Riyanto. (2010). Membuat Sendiri Sistem Informasi Penjualan dengan PHP dan MYSQL Edisi 1. Gava media.

Satzinger, J. W., Jackson, R. B., \& Burd, S. D. (2012). Systems Analysis and Design in a Changing World, 6th Edition.

Supriyanto, R. (2016). Sistem Informasi dan Administrasi pada Boutique Tradisional. Universitas Indraprasta PGRI.

Tantra, R. (2012). Manajemen Proyek Sistem Informasi. CV Andi Offset.

Welim, Y. Y., \& Afifi, N. R. A. (2017). Rancang Bangun Sistem Informasi Jasa Barbershop. Bit, 14(2), 1-8. 